\title{
Molinism and divine prophecy of free actions
}

\section{GRAHAM OPPY}

School of Philosophical, Historical and International Studies, Monash University, Clayton Campus, Wellington Road, Clayton VIC 3800 AUSTRALIA

Graham.Oppy@monash.edu

\section{MARK SAWARD}

School of Philosophical, Historical and International Studies, Monash University, Clayton Campus, Wellington Road, Clayton VIC 3800 AUSTRALIA

Mark.Saward@monash.edu

Abstract: Among challenges to Molinism, the challenge posed by divine prophecy of human free action has received insufficient attention. We argue that this challenge is a significant addition to the array of challenges that confront Molinism.

We think that divine prophecy of free actions generates a difficult problem for Molinists. Our aim here is to set out the problem, and to explain why we think that this problem has not yet been satisfactorily addressed by Molinists. We begin with a quick characterization of Molinism-largely following Flint (1998), but also following, e.g., Craig (1987), Freddoso (1991), Kvanvig (1986), Plantinga (1974), van Inwagen (1997), Wierenga (1991) and Zagzebski (1991) -and a tour of some of the major objections that have been lodged against it. We then state our new objection, and consider possible replies.

Molinism Outlined

According to Molinism, God has prevolitional natural knowledge, and prevolitional middle knowledge, but only postvolitional free knowledge. God's natural knowledge is God's knowledge of necessary propositions that are not under God's control; God's free knowledge is God's knowledge of contingent propositions that are under God's control; and God's middle knowledge is God's knowledge of contingent propositions that are not under God's control. God's middle knowledge includes God's knowledge of counterfactuals of creaturely freedom, i.e. counterfactuals of the form:

If creaturely essence $\mathrm{P}$ were instantiated in (logically and causally non-determining) complete circumstances $C$ at time $t$, the instantiation of $P$ would do $A$.

A complete circumstance includes all of the causal factors that bear on the behaviour of the instantiation of $\mathrm{P}$ at $\mathrm{t}$, including all of the prior causal activity of all agents. 
God's creative act of will is constrained both by his natural knowledge and by his middle knowledge. On the one hand, God cannot actualize an impossible world; on the other hand, God cannot actualize a world in which creatures act contrary to relevant counterfactuals of creaturely freedom. However, God's creative act of will is not constrained by his free knowledge: on the contrary, his free knowledge is, like the subsequent actualization of the world, a consequence solely of his creative act of will. Moreover, God's creative act of will is not just a decision about which world to actualize; it is also a decision about which world would have been actualized had God's middle knowledge been different, for every complete way that God's middle knowledge could have been different. Finally, God's creative act of will is free, at least in the following sense: God could have made a different decision about which world to actualize given the middle knowledge that he had; and God could have made different decisions about which world would have been actualized had God's middle knowledge been different, for every complete way that God's middle knowledge could have been different. (Perszyk (2011) contains a fairly comprehensive bibliography of recent work on Molinism, and a very useful introductory overview.)

An Initial Problem

Our characterization of Molinism generates an immediate problem. If a complete circumstance includes all of the prior causal activity of all agents, then a complete circumstance includes the creative activity of God (because the creative activity of God is causal, and God is an agent). But, if complete circumstances include the creative activity of God, then it seems that there will not beand, indeed, cannot be-any complete circumstances that are 'logically and causally nondetermining'. After all, if, causally upstream from the circumstances in which an instantiation of $P$ is to act, God has decided to actualize the world to which that instantiation of P belongs, then God has taken a relevant counterfactual of creaturely freedom into account in deciding which world to actualize. But, if God has actualized the world in part because, if placed in the circumstances in question, an instantiation of $\mathrm{P}$ would do $\mathrm{A}$, then it seems that God's creative decision at least logically determines that $\mathrm{P}$ does $\mathrm{A}$ : there is no logically possible world that God decides to actualize, in part, because, if placed in the circumstances in question, an instantiation of $P$ would do $A$, and yet in which that instantiation of $P$ does not do $A$. Moreover, it seems that it can also be argued that, if God has actualized the world in part because, if placed in the circumstances in question, an instantiation of $P$ would do A, then God's creative decision causally determines that P does A: for, on the hypothesis in question, $\mathrm{P}^{\prime} \mathrm{s}$ doing $\mathrm{A}$ belongs to the one and only causal history that can ensue from the particular creative decision that God took.

Some may think that the expression of our worry rides roughshod over the distinction between direct causes and indirect results of direct causes -or, equivalently, the distinction between strong actualization and weak actualization-which Flint illustrates with the following example: while Henry II strongly directly caused his own utterance of the words 'Will no one rid me of this turbulent priest', the death of Thomas a 'Becket was only the indirect result of his direct causing of his own utterance of those words. However, Flint's own example serves to show that the distinction has no application in the present case-for, of course, a 'Becket's death can only be an indirect result of 
Henry II's words if there are independent causes that join with Henry II's utterance to bring the four knights to Canterbury Cathedral to murder a 'Becket. But, in the case of God's creation, there are no independent causes that join with God in the actualization of the world: indeed, on the Molinist picture, there is nothing in the world that is, in any relevant sense, causally independent of God's creative act.

Since there is risk of misunderstanding here, it is perhaps worthwhile for us to add that, while the prevolitional status of middle knowledge does nothing to alter the fact that God is the cause of everything in the world (other than God), the prevolitional status of middle knowledge does make a difference to the sense in which God is responsible for various features of the world. On the one hand, God's natural knowledge and God's middle knowledge are constraints on God's creative activities: at least in the latter case, God might have preferred that what he knows through his middle knowledge were other than it is; but, on the other hand, God's free knowledge reflects the outcome of a free decision that God makes taking the constraints imposed by his natural knowledge and his middle knowledge into account. God's creation in the light of his middle knowledge need not be understood as a full endorsement of what is known to him through his middle knowledge: perhaps some things that are caused by God are fully willed by God; but other things that are caused by God receive a less enthusiastic endorsement from him.

On the assumption that our worry is well-taken, we should amend the account of counterfactuals of creaturely freedom, taking them to be all counterfactuals of the following form that have a contingent truth-value prior to God's creative decision:

If creaturely essence $P$ were instantiated in complete circumstances $C$ at time $t$, the instantiation of $P$ would do $A$.

Henceforth, we assume that this amendment has been made.

Familiar Objections

Molinism faces a number of fairly well-worn objections, the first of which was largely aired in the preceding section.

1. There can be no such things as counterfactuals of creaturely freedom-contingently true claims of the form if creaturely essence $P$ were instantiated in complete circumstances $C$ at time $t$, the instantiation of $P$ would do $A$-if God exists and has the creative role that Molinists assume. For, if God exists and has the creative role that Molinists assume, then any complete specification of circumstances will include the fact that God created taking into account the fact that, for example, A would do $X$ were these very circumstances to arise. But it is a necessary truth that, if God actualizes a world taking account of the fact that $A$ would do $X$ in $C$ were that very world actualized, then $A$ does $\mathrm{X}$ in $\mathrm{C}$ in that world. In other words, for any complete specification of circumstances, it is not a contingent matter whether the instantiation of $\mathrm{P}$ would do $\mathrm{A}$ in those completely specified circumstances. (See Hasker (1989) (2011).) 
2. If there were to be such things as counterfactuals of creaturely freedom true prior to God's creative act, then there would be ungroundedly true counterfactuals of creaturely freedom. But, quite generally, there cannot be ungroundedly true claims; and, more specifically, there cannot be ungroundedly true counterfactuals. Of course, the prospects for making out this objection depend upon the further assumptions that one is prepared to make about grounding and truth-making, and upon the metaphysical commitments that one is prepared to take on. But if, for example, one is inclined to think that all true claims must be grounded in the actual properties of actual things, then it is hard to see how one could also think that there could be counterfactuals of creaturely freedom true prior to God's creative act, when God is the only thing that exists, and the counterfactuals of creaturely freedom are supposed to be true independently of God. (See Adams (1987) and Zimmerman (2011).)

3. Suppose that, as argued above, it is not a contingent matter whether an instantiation of $P$ would do $A$ in any completely specified circumstances. Then, clearly, if $A^{\prime}$ 's doing $X$ in those completely specified circumstances is to be free, the notion of freedom at issue cannot be one that accepts the Principle of Alternative Possibilities. For the Principle of Alternative Possibilities tells us that one acts freely only if, in the complete circumstances in which one acts, one could have done other than one actually did. Of course, whether one views this as an objection to Molinism depends upon the attitude that one takes towards the Principle of Alternative Possibilities. Some say that what really matters for freedom is whether an agent has counterfactual power over the past: whether it is true that, had the agent done otherwise, the past would have been different. But even a hard determinist who thinks that the laws are necessary can suppose that agents have counterfactual power over the past in that sense. So, at the very least, those Molinists who would eschew the Principle of Alternative Possibilities have unfinished business explaining their conception of freedom.

4. Friends of the Consequence Argument against compatibilism may well be tempted by the following objection to Molinism. Suppose that an agent $S$ freely performs an action $A$ in circumstances $\mathrm{C}$. Given that counterfactuals of creaturely freedom are true prior to God's creative activity-and constrain that creative activity-it seems that $S$ has no choice about whether, if $S$ were in $C, S$ would freely do $A$, nor any choice about whether $S$ is in circumstances $C$. But, if $S$ has no choice about whether, if $S$ were in $C, S$ would freely do $A$, and $S$ has no choice about whether $S$ is in circumstances $C$, then $S$ has no choice about whether $S$ freely does $A$. But friends of the Consequence Argument cannot accept that $S$ has no choice about whether $S$ freely does $A$ : for them, it is constitutive of $S^{\prime}$ 's freely doing $A$ that $S$ has a choice about whether $S$ does $A$. Of course, not everyone accepts the Consequence Argument: but libertarians who do not accept the Consequence Argument at least have unfinished business explaining why they are libertarians. (See Perszyk (1998) and Mares and Perszyk (2011).)

5. Molinism relies crucially upon a conception of complete circumstances of action. Flint ((1998), 47) tells us that the complete circumstances of an action include everything that is causally anterior to the action. But Flint ((2011), 40) says that the complete circumstances of an action include only those causally anterior things that are 'fixed, settled and utterly beyond our control'. However, if we suppose that we have 'counterfactual power' over God's creative decision, then a serious question arises whether there is anything causal that belongs to the complete circumstances of an action. And 
if there isn't anything causal that belongs to the complete circumstances of an action, then it is unclear what the complete circumstances of an action are supposed to be.

Here's the nub of the problem. We suppose that there is an actual world type that constrained God's creative decision: God considered a range of feasible worlds, and selected one to actualize. We suppose, further, that, if any agent had made a different choice at some point, then a different world type would have constrained God's creative decision: God would have considered a different range of feasible worlds. Of course, if one agent had made a different choice at some point, then many subsequent decisions would also have been different: some 'new' complete circumstances of decision would occur, and some 'old' complete circumstances of decision would not. But, even if there were only one different creaturely choice, it is clear that there is nothing that guarantees that God would then have chosen to actualize a very similar world. God's creative choice is a global decision-a choice from a set of feasible worlds-and there just is no reason to suppose even that there are some creatures in common between God's 'first choice' world and his 'second choice' world. In other words: there is no reason to suppose that there is any part of the complete circumstances that would have remained in place had God chosen from the set of feasible worlds that would have been presented to him had there been the different creaturely choice that we are envisaging. But if no causal part of the complete circumstances would have remained in place had God chosen from the set of feasible worlds that would have been presented to him had there been the different creaturely choice that we are envisaging, and if the complete circumstances of an action include only those causally anterior things over which we do not have counterfactual control, then it seems that there might be nothing causally anterior that belongs to the complete circumstances of an action. And, in that case, we are at a loss to imagine what would be part of the complete circumstances of those actions.

\section{Prophecy of Free Actions}

We have a further objection to add to the preceding stock. We think that this objection is new, and that it is worthy of serious consideration. (See Flint (1998) and Warfield (2009) for some related discussion.)

Suppose that God can make prophecies to the effect that certain agents would freely perform certain actions in certain circumstances. Through his natural knowledge, God knows that, necessarily, if God prophesies that an agent $A$ will freely perform an action $X$ in complete circumstances $C$, then A freely does $X$ in $C$; indeed, God knows the instances of this claim for any agent $A$, any action $X$, and any complete circumstance $C$. But, given that, prior to creation, God has all of this natural knowledge, it seems that it is open to God to make a world that is full of divine prophecies: for every agent A, and every circumstance $C$ in which that agent performs a free action, God prophesies that the agent freely performs a morally good action $X$ in those circumstances. Given that the world is full of these divine prophecies, the world will be a Mackie world: a world in which all agents always freely choose the good. (See Mackie (1982), 164.) But given that, all else being equal, Mackie worlds are better than non-Mackie worlds, why then isn't our world a world in which all agents always freely choose 
the good? Moreover, given that, no matter what world-type is taken to constrain the worlds that it is feasible for God to actualize, it will always be open to God to make Mackie worlds, and given that, all else being equal, Mackie worlds are better than non-Mackie worlds, why isn't it the case that any world that God can make is a world in which all agents always freely choose the good?

One possible response to this argument is to deny that God can make prophecies to the effect that certain agents would freely perform certain actions in certain circumstances. While this response is clearly sufficient to avoid the problem, it is not a response that all Christians will be willing to accept. After all, many Christians do allow that God can make prophecies that people will freely choose to do certain things at particular times and places. Consider, for example, the account of Peter's denial of Christ (at Matthew 26:34, Mark 14:30, Luke 22:34 and John 13:38). When Jesus says: "Before the cock crows, you will deny me three times", it seems to be clearly implicit in what Jesus says that Peter's denial of him will be both culpable and voluntary. But, if that is right, then the content of the prophecy that Jesus makes is, at least in part, that Peter will freely deny him three times before the cock crows. Add the further Christian belief that Jesus is God, and we clearly do have a case in which it is being supposed that God has made a prophecy to the effect that someone will freely choose to perform particular actions (at a particular time). ${ }^{1}$

Consider, then, those Christians who do allow that God can make prophecies that people will freely choose to do certain things at particular times and places. How might they respond to our argument? Perhaps they might think to object that God's natural knowledge, that if God prophesies that an agent $A$ will freely perform an action $X$ in complete circumstances $C$, then $A$ freely does $X$ in $C$, is only substantive if God also has middle knowledge that, if $A$ were instantiated in $C$, then $A$ would freely do X in C. After all, they might add, if it is not true that, were A instantiated in C, A would freely do X, then it cannot be that God prophesies that A will freely do X in C: and if it cannot be that God prophesies that $A$ will freely do $X$ in $C$, then it is merely trivially true that, if God prophesies that $A$ freely does $\mathrm{X}$ in $\mathrm{C}$, then $\mathrm{A}$ freely does $\mathrm{X}$ in $\mathrm{C}$.

We do not think that this response is viable. By hypothesis, we are talking about complete circumstances. In the envisaged complete circumstances, God prophesies that A freely does X in C. But, of course, in any such complete circumstances, $A$ freely does $X$ in $C$. When we are asked to consider that God might have middle knowledge that entails that, were A instantiated in C, A would not freely do $X$ in $C$, we can only suppose that God might have such middle knowledge if we consider complete circumstances in which God does not prophesy that A freely does X in C. Alas, however, any such complete circumstances are obviously irrelevant: they are not the complete circumstances that we are supposed to be entertaining. So this response is an evident non-starter. Whatever barriers there might be to God's creating while paying no attention to his middle knowledge, it cannot be that God's middle knowledge threatens to trivialise some of his natural knowledge.

A different possible response is that, if God were to make universal prophecy about what his creatures will do-i.e. for each creature, and each circumstance in which that creature is placed, prophesy what that creature will do-then his universal prophecy would determine the actions of those creatures, and so their actions would not be free. If this is right, then it is incoherent to suppose that God make universal prophecy about what his creatures will freely do: for, in making 
universal prophecy about what his creatures will freely do, God would be making universal prophecy about what his creatures will do.

We think that this objection is not available to Molinists. Compare the following two scenarios. In the first scenario, God's initial creative action is to make an angel. God tells the angel exactly how the rest of creation will go. God then destroys the angel, and goes on to actualise the rest of creation. In the second scenario, God skips the angel, and goes directly to the actualisation of what was in the first scenario the rest of creation, but in this second scenario is the whole of creation. On this second scenario, not all free creaturely actions are prophesied-and perhaps few or none are. However, on the first scenario, all free creaturely actions are prophesied to the angel. Given that Molinists allow that there can be free actions in the second scenario, they are surely obliged to admit that there can be free actions in the first scenario as well: but then they are also obliged to admit that freedom of action is compatible with universal prophecy. Whatever is objectionable about God's creating while paying no attention to his middle knowledge, it cannot be the universality of his prophesying that is at fault.

Another possible response is that the very idea that God might make free creatures while paying no attention to his middle knowledge is incoherent: in order for a creature to act freely on a particular occasion, there must be a relevant counterfactual of creaturely freedom that figured in God's middle knowledge prior to creation. If $A$ freely does $X$ in complete circumstances $C$, then, on the Molinist way of seeing things, it was part of God's middle knowledge prior to creation that, were $A$ to be placed in C, A would freely do X.

We demur. True enough, Molinists are required to suppose that, if $\mathrm{A}$ freely does $\mathrm{X}$ in complete circumstances $C$, then it was part of God's knowledge prior to creation that, were A to be placed in C, A would freely do X. But granting this much is simply insufficient to determine whether, in any particular case, the knowledge that is being granted to God is part of God's middle knowledge or part of God's natural knowledge. If the complete circumstances contain relevant prophecy on God's part, then, we say, the knowledge in question is part of God's natural knowledge prior to creation. If there is something incoherent in the idea that God might make free creatures while paying no attention to his middle knowledge, it is not that, by Molinist lights, we are incoherently denying that, in order for a creature to act freely on a particular occasion, there must be a relevant counterfactual of creaturely freedom that figured in God's knowledge prior to creation.

A final response upon which we should provide some comment suggests that the picture that we have sketched is incoherent: we have suggested that any world that God can make is a world in which all agents always freely choose the good, and yet we have also supposed that many of the feasible worlds from which God selects are not worlds in which all agents always freely choose the good.

We think that this response is based on misunderstanding. Our aim is to argue that the Molinist position is untenable. If there is incoherence here, it is incoherence within Molinism. But it is not clear that there is really incoherence here. It is quite common for theorists to develop views on which God makes creative choices from domains stacked to the gills with impossible worlds. Such theorists may claim either that there is nothing wrong with this kind of commitment to impossible worlds or else that the apparent commitment to impossible worlds can be explained away on a 
more careful formulation of the theories in question. If theories that have God making creative choices from domains that include impossible worlds are ruled out on those grounds alone, then, we think, Molinism is clearly in trouble; but we doubt that theories can be ruled out on those grounds alone.

\section{A Final Word}

A question arises about the significance of our new argument. As we noted earlier, there are already several well-worn objections to Molinism. However, there are still plenty of Molinists who suppose that they have adequate responses to those well-worn objections. Do we think that our argument can do what those previous objections could not: bring Molinists to the realisation that they ought to give up on their Molinism?

Of course not! If the well-worn arguments won't do the job, then our argument won't do it either. However, it may be that adding our argument to the existing stack of arguments makes it just that little bit harder for Molinists to navigate their way through the difficulties that the collection of arguments makes for them. As more arguments are added to the stock, the question is: can Molinists simultaneously work their way past all of these arguments?

\section{References}

ADAMS, R. (1987) The Virtue of Faith and Other Essays in Philosophical Theology (Oxford: Oxford University Press)

CRAIG, W. (1987) The Only Wise God: The Compatibility of Divine Foreknowledge and Human Freedom (Grand Rapids: Baker Book House)

FLINT, T. (1998) Divine Providence (Ithaca: Cornell University Press) (2011) 'Whence and Whither the Molinist Debate: A Reply to Hasker' in Perszyk (ed.) (2011), $37-$ 49

FREDDOSO, A. (1991) 'Introduction' to his annotated translation of Luis De Molina's On Divine Foreknowledge (Part IV of the Concordia) (Ithaca: Cornell University Press), 1-81

HASKER, W. (1989) God, Time and Knowledge (Ithaca: Cornell University Press) (2011) 'The (Non-)Existence of Molinist Counterfactuals' in Perszyk (ed.) (2011), 25-36

KVANVIG, J. (1986) The Possibility of an All-Knowing God (New York: Macmillan)

MARES, E. and PERSZYK, K. (2011) 'Molinist Conditionals' in Perszyk (ed.) (2011), 96-117

MACKIE, J. (1982) The Miracle of Theism (Oxford: Clarendon)

PERSZYK, K. (1998) 'An Anti-Molinist Argument' Philosophical Studies 90, 215-35 (ed.) (2011) Molinism (Oxford: Oxford University Press)

PLANTINGA, A. (1974) The Nature of Necessity (Oxford: Clarendon)

VAN INWAGEN, P. (1997) 'Against Middle Knowledge' in P. French, T. Uehling and H. Wettstein (eds.) Midwest Studies in Philosophy 21, 225-36

WARFIELD, T. (2009) 'Ockhamism and Molinism-Foreknowledge and Prophecy' Oxford Studies in Philosophy of Religion 2, 317-32

WIERENGA, E. (1991) 'Prophecy, Freedom and the Necessity of the Past' in J. Tomberlin (ed.) Philosophical Perspectives 5 (Atascadero: Ridgeview) 
ZAGZEBSKI, L. (1991) The Dilemma of Freedom and Foreknowledge (Oxford: Oxford University Press) ZIMMERMAN, D. (2011) ‘An Anti-Molinist Replies' in Perszyk (ed.) (2011), 163-86

\footnotetext{
${ }^{1}$ Suppose that freedom to act is necessary for responsibility, and responsibility is necessary for immorality. Then, any divine prophecy that a particular person would perform a particular immoral act at a particular time and place would also be a divine prophecy that a person would freely act in a particular way at a particular time and place. (Compare Flint (1998), 201ff.).)
} 